Animal Health Research Institute, Assiut Regional Laboratory,

Dept. of Food Hygiene.

\title{
LIPOLYTIC AND PROTEOLYTIC ACTIVITIES OF SOME FUNGI ISOLATED FROM RAW CAMEL'S MILK
}

(With 2 Tables)

By

\section{EMAN KORASHY and NAHED MOHAMED WAHBBA}

(Received at 10/6/2008)

\section{قدرة التحلل الاهنى والبروتينى لبعض الفطريات المعزولة

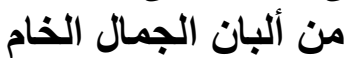

\section{إيمان قرشى ، ناهل محمد وهبه}

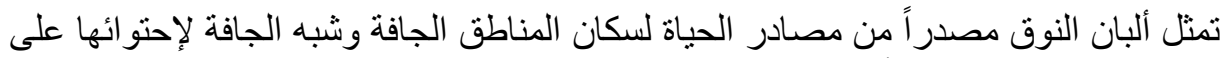

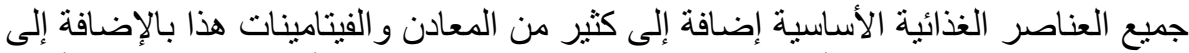

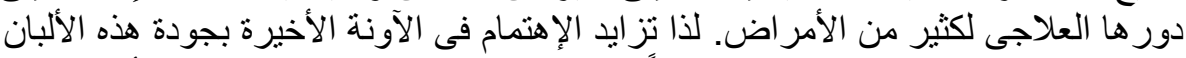

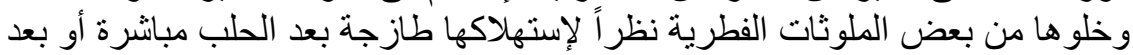

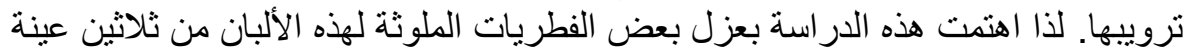

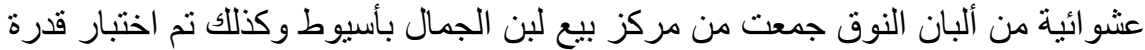

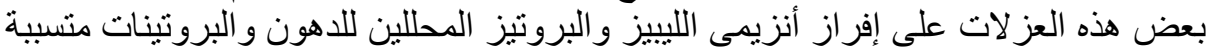

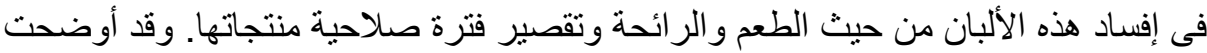

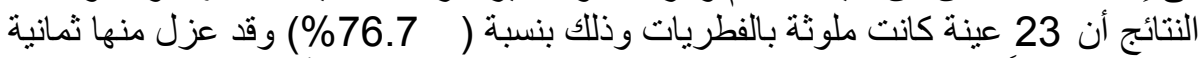

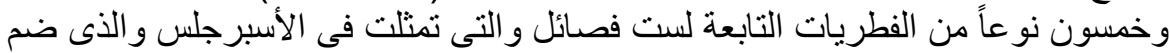

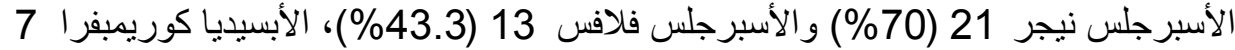

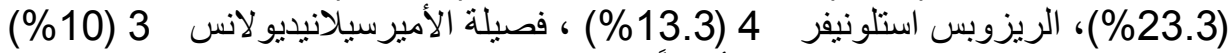

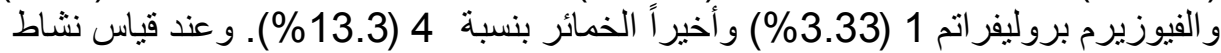

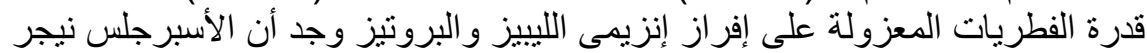

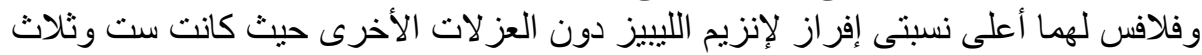

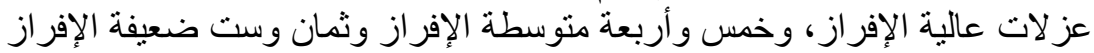

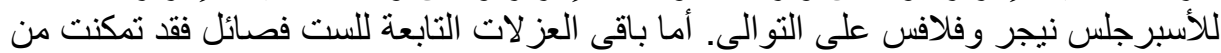

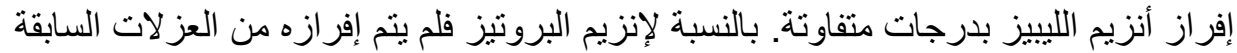

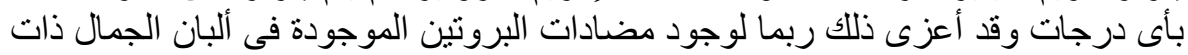

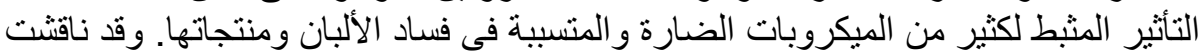

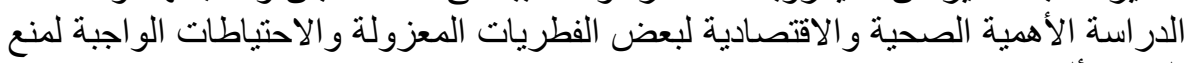
تلوث الألبان ومنتجاتها. الاهنة 


\section{SUMMARY}

A total of 30 raw camel's milk samples randomly collected from a camel Milk Center in Assiut were subjected to fungal analysis and then screening the isolated fungi to enzymatic activations. Results of isolation revealed that: $23(76.7 \%)$ of the examind samples were contaminatd by 58 fungal species belonging to 6 genera. Aspergillus, Absidia corymbifera, Rhizopus stolonifer, Emericella nidulans, Fusarium proliferatum and yeasts. The most predominant species capable to secrete lipase enzyme were A. niger 21 (70\%) and A. flavus 13 (43.3\%) while the other fungal species could produce lipase enzyme with variable degrees. Protease enzyme could not be detected from all the isolated fungal species and this may be attributed to the protease inhibitors presented in camel's milk. The health and economic significances of the isolated fungi were also discussed.

Key words: Camel's milk, lipase, protease enzymes.

\section{INTRODUCTION}

Camel milk is an important factor in the economic life and for survival of many nomads in the drier areas and desert dwellers where no other animal can produce milk due to stress conditions. A she camel yields daily from 3.5 to $35 \mathrm{~kg}$ of milk containing all essential nutrients and exceeds in vitamins and minerals more than that find in milk from other species (Farah, 1993). Camel's milk has a large scale of medical treatment for number of diseases and illnesses from diarrhea to tuberculosis, reducing the coronary heart diseases and diabetes (Roae et al., 1970 and Zagorski et al., 1998). Traditional therapeutic uses of camel milk in folk medicine in different areas in the world were recorded due to its antibacterial and antiviral properties (Yagil, 1982). Camel's milk is gaining popularity by nomads who consumed it fresh immediately after milking in a raw state or just after mild souring (FAO, 1992) therefore, much attention has been given to produce high quality raw camel's milk with minimal microbial contamination (Robinson, 1990). The microbiological quality of raw camel's milk was studied by Al-Mohizea (1986), Mahmoud (1997), Teshager and Bayleyen (2001), Khedid et al. (2003) and Korashy et al. (2006). Fungi including the mycotoxic species are among the contaminating hazardous that influence the safety of raw milk. A potential relationship between human 
consumption of moldy foods and various illnesses has been long suspected (Stoloff, 1976). Molds constitute a part of normal flora inhibit camel wool (Bagy and Abdel Hafez, 1985) and consequently may be a source of camel's milk contamination during the milking process. Recently, microbiologists focused their attation on yeasts as food spoilage causitive organisms and the role of pathogenic yeasts affecting human health through consumption of raw milk (Spillman and Ceiges, 1983 and Hurley et al., 1987). The occurrence of yeasts in raw milk was reported by some investigators in different countries (Bridge Cooke and Brazis, 1968, Haridy, 1992 and Mahmoud, 1997). Yeast and mould counts are usually used as a guide for proper sanitation and an index of the quality control of dairy products (Foster et al., 1983).

Mycotoxins are fungal metabolites proved to be etiological agents in some outbreaks of foodborne diseases of human and animals (Wyllie and Morehouse, 1977). Many of fungi are mycotoxin producers. These mycotoxins are carcinogenic, mutagenic and teratogenic such as aflatoxins, ochratoxin A and sterigmatocystin (Chu, 1991). An outbreak of hepatitis infected 400 indian people of whome 100 died resulted from aflatoxin contaminated maize ration fed to animals (Krishnamachari et al., 1975). Although, some species of molds are used in manufacturing and ripening of certain varieties of some milk products they are responsible for lipolytic and proteolytic spoilage including discolouration, rancidity, off flavour and poor appearance which often result in downen grading of milk and milk products leading to economic losses (Jakobsen and Narvhus, 1996). Temporal bitterness in some soft cheese manufactured from camel's milk reported by Layer and Keller et al. (2003). So there is an increasing demand by the dairy industry for high quality raw milk free from pathogenic and spoilage microorganisms (Desmasures et al., 1997). Braun et al. (2002), Ali and Abo-Al-Yazeed (2003) and Saxena et al. (2003) delt with lipolytic and proteolytic activities of fungi produced from camel's milk. Lipase enzyme still to be the main factor responsible for camel's milk spoilage as the bacteriolytic nature of camel's milk protein including lysozymes, lactoferrin, lactoperoxidase, immunoglobin and the $\mathrm{N}$-acetylglucosaminidase which inhibit the growth of some pathogenic and spoilage organisms (Al-Naki, 1984). Protein inhibitors in camel's milk explain the traditional therapeutic uses of this milk in folk medicine in different areas in the world (Yagil, 1982). 
In general, lipolytic and proteolytic activities expressed to the primary microbial spoilage enzymes of dairy products which are responsible for deleterious effects in milk and its products (Stelma, 1989). Both lipases and proteases are heat stable extracellular enzymes produced by spoilage microflora resulting in off flavour described as rancid, unclean, soapy and bitter (Conesa et al., 2001) due to lipid and protein degradation (Downey, 1980) and adversely affects the processing properties of milk and the quality of milk products (Cormie, 1992) which consequently leading to economic losses through the unacceptability and reduction of the shelf-life time of the product. Much attention has been given to lipolytic activity screened by different microflora in camel's milk (Kotula et al., 1982; Favale et al., 1994; Abu-Tarboush et al., 1998 and Ali and Abo Al-Yazeed, 2003).

Regarding to the health and economical points of fungi and their lipid activities this study was designed to:

1- Survey fungi (mould and yeast) which contaminate raw milk.

2- Screening the capabilities of the isolated fungi for lipase and protease enzymes production.

\section{MATERIALS and METHODS}

\section{Collection and preparation of samples}

A random collection of 30 raw camel's milk in clean, dry and sterile containers were transferred to the laboratory without delay and kept at $4^{\circ} \mathrm{C}$ until fungal analysis. Each sample was throughly mixed and subjected to storch test according to Lampert (1975) to exclude the heat treated samples.

\section{Mycological analysis}

Isolation of fungi: Using sabaroud dextrose agar (Difco Lab) according to Harrigan and McCance (1976) with antibiotic for characterization of the mycoflora contaminated the milk samples. The cultured plates were incubated at $25^{\circ} \mathrm{C}$ for 5-7 days. The developing fungi isolated and identified according to Raper and Fennel (1965) and Ellis (1971).

\section{Enzymatic activities:}

A- Lipolytic activity: was detected according to Ullman and Blasins (1974).

B- Proteolytic activity adopted according to Paterson and Bridge (1994). 


\section{RESULTS}

The obtained results were tabulated in Tables 1 and 2 .

Table 1: Incidence of mould and yeast in the examined samples of raw camel's milk.

\begin{tabular}{|c|c|c|}
\hline No. of examined samples & +ve samples & $\%$ \\
\hline 30 & 23 & 76.7 \\
\hline
\end{tabular}

Table 2: Incidence of fungal species and their lipolytic activity in the examined raw camel's milk samples.

\begin{tabular}{|l|c|c|c|c|c|c|}
\hline \multirow{2}{*}{ Isolated fungal species } & \multirow{2}{*}{ NIT } & \multirow{2}{*}{$\%$} & \multicolumn{4}{|c|}{ Lipolytic activity } \\
\cline { 4 - 7 } & & & NIP & H & M & W \\
\hline A. niger & 21 & 70 & 19 & 6 & 5 & 8 \\
A. flavus & 13 & 43.3 & 13 & 3 & 4 & 6 \\
A. terreus & 4 & 13.3 & 4 & 1 & 2 & 1 \\
A. fumigatus & 1 & 3.3 & 1 & 1 & - & - \\
Absidia corymbifera & 7 & 23.3 & 7 & 7 & 5 & 1 \\
Rhizopus stolonifer & 4 & 13.3 & 2 & 1 & - & 1 \\
Emericella nidulans & 3 & 10 & 3 & 3 & 1 & \\
Fusarium proliferatum & 1 & 3.3 & 1 & 1 & - & 1 \\
Yeasts & 4 & 13.3 & 4 & 4 & 2 & 1 \\
\hline Total & 58 & & 54 & 27 & 19 & 19 \\
\hline
\end{tabular}

Total number of examined samples $=$ No. 30

NIT $=$ number of isolates tested.

NIP = number of isolates positive

$\mathrm{H}$ : high M: moderate W: weak

\section{DISCUSSION}

Table 1 showed that the incidence of fungi isolated from the thirty raw camel's milk samples were 23 (76.7\%). Higher results were obtained by Mahmoud (1997) and Ali and Abo Al-Yazeed (2003), lower results were obtained by Khedid et al. (2003). The high incidence of fungi in the examined raw milk samples may be attributed to the widespread distribution of fungi in nature. Fungi are normal inhibitant of wool of the animal, also, ability of fungi to be adopted at wide range of temperatures (Nasser et al., 1998). The high incidence of fungal contamination not only be responsible for the public health hazard through the wide variety of mycotoxin production affecting humans and 
animals (Mossel, 1982) but also it may lead to economic losses through milk spoilage by lipase enzyme which leads to inferior quality of milk specially when long stored and when it is manufactured (Jakobsen and Narvhus, 1996). Table 2 clarified that raw camel's milk tested became molded by fifty eight fungal species which were belonging to six genera. Aspergillus was the common genus and it was represented by 4 species of which A. niger $21(70 \%)$ and A. flavus $13(43.3 \%)$, A. terreus $4(13.3 \%)$ and A. fumigatus $1(3.33 \%)$ were recorded with lower incidence. The same results were obtained by Ali and Abo Al-Yazeed (2003) who found that genus Aspergillus was the mot prevealant in fifty raw camel's milk samples.

A. niger is one of the best known of all fungal species and it is regarded as a benign fungus. So, it is categorized as safe by the U.S. Governorate. It has been widely used in food processing since the toxin production does not appear to be common (Abarca et al., 1994). A. niger is more prevealant in warmer climates in field satuation and stored foods (Ayerst, 1966).

On the other side, A. flavus is the most important natural source of aflatoxins in the world's food supplies of which are $B_{1}, B_{2}, G_{1}$ and $G_{2}$. The risk of $\mathrm{B}_{1}$ and $\mathrm{B}_{2}$ aflatoxins starts when they ingested by a lactating animal and a proportion is hydroxylated to $\mathrm{M}_{1}$ and $\mathrm{M}_{2}$ aflatoxin derivitives of lower toxicity but their significant due to the widespread consumption of mycotoxicated milk by infants (Frobish et al., 1986). Aflatoxins produced by A. flavus exposed animals including man to acute and chronic toxicity distincted in four forms: liver damage, liver cirrhosis, induction of tumours and teratognic effects. A wide range of metabolites were produced by A. terreus and of these only territrems appear to have significant toxicity (Frisvad and Samson, 1991).

A. fumigatus has a marginal xerophile nature ranges from $12^{\circ} \mathrm{C}$ to $55^{\circ} \mathrm{C}$ (Ayerst, 1966). A. fumigatus produces number of toxins of which fumitremorgens, verruculogen and gliotoxin which is the only important in the invasion of the animal (Richard et al., 1994). Other infections to eye, skin, sinusis and lungs (pulmonary Aspergillosis) were reported by (Hog et al., 2000) due to genus Aspergillus. A. niger and A. flavus recorded the highest degree of lipase production among the fifty eight fungal species tested for screening of lipase, Table 2. Ninteen and thirteen tested isolates representing A. niger and A. flavus respectively revealed 6 and 3 for high, 5 and 4 with moderate and 8 and 6 with weak production for lipase enzyme. The same results were recorded by Ali and 
Abo Al Yazeed (2003) who tested ninty mold isolates for detection of lipase activity and they found that seventy isolates were positive and genus Aspergillus domenated the other genera for lipase production.

Following up Table 2, it is obvious that Absidia corymbifera occupied the second genus in occurrence 7 (23.3\%). It was rarely to be isolated from milk and its products by several examinators. It is a widespread species in tropics. It could be isolated from group of cereals used in animal and human feeding (Dragoni et al., 1979). A. corymbifera is a weak human and animal pathogen although its wide host range and capable of infecting many body organs (Lunn, 1977). Only 5 of the 7 tested isolates were moderate for lipase production. Rhizopus stolonifer scored 4 (13.3\%), (Table 2). High and weak lipase production by R. stolonifer were recorded by one isolate for each. Emericella nidulans scored $3(10 \%)$. It could be isolated from milk and other dairy products by Korashy and Hussein (2005). It is a marginal thermophile has been isolated from a wide variety of sources (Moubasher et al., 1972). It has been reported to produce sterigmatocystin and emestrin which is highly toxic (Terao et al., 1990). High, moderate and weak production of lipase were represented by one isolate for each from the three E. nidulans tested isolates. Fusarium proliferatum recoded weak occurrence with weak production of lipase enzyme. It is worth to mention that lipase production did not differ among the different mold species but also among the isolates of the same species, (Table 2).

Yeasts derived from fungal analysis of raw camel's milk samples revealed 4 (13.3\%). Different results concerning this line recorded by several examinators from raw milk as Haridy (1992), Mahmoud (1997), Sabry (2001), Al-Ganzoury (2002). High incidence of these organisms in raw milk is indicative of unsatisfactory sanitation during the milking journey as they gain enterance to raw milk from the contaminated air, water, dust, utensils. Hurley et al., 1987 studied the pathogenesis of some yeast strain isolated from raw milk consumed by human. Lipase production by yeast species recorded one isolate for high and weak production and two isolates with moderate production. Ottogalli and Galli (1972) recoded lipolytic activity by yeasts which is responsible for rancid and off flavour attributed to the undesirable changes and inferior quality of milk specially during long storage and processing (Conesa et al., 2001).

Protease activity could not be detected from all fungal species tested and this is attributed to the protease inhibitors which may be found 
in camel's milk inhibiting the growth of saprophytic and pathogenic organisms (Al-Naki, 1984 and Farah, 1993). So, lipase enzyme still to be the main factor affecting the milk spoilage.

Finally, it could be concluded that raw camel's milk is strongly liable to be contaminated with several fungal species as they are normal inhibitant of the camel wool and adapt themselves at a wide range of environmental conditions. Strict hygienic measures must be applied during the milking process including, animal, milkers, utensils and equipments since, the nomad and the young camels consume this milk in its raw state. Greater attention must be focused on the antimicrobial property of camel milk to improve preservation conditions of milk specially when it is transformed to cheese or other fermented dairy products to creat the bright future demand to camel's milk.

\section{REFERENCES}

Abarca, M.L.; Bragulat, M.R.; Castella, G. and Cabanes, F.J. (1994): Ochratoxin A production by strains of Aspergillus niger var. niger. Appl. Environ. Microbiol. 60: 2650-2652.

Abu-Tarboush, H.M.; Al-DaGal, M.M. and Al-Royli, M.A. (1998): Growth, viability and proteolytic activity of Bifidobacteria in whole camel milk. J. Dairy Sci. 81: 354-361.

Al-Ganzoury, H.H. (2002): Chemical and Microbiological Quality of Ewes Milk. SCVMJ, V (1) 43-50.

Ali, S.A. and Abo-Al Yazeed, H. (2003): Microbiological studies on camel milk in North Sinai, Egypt. J. of Camel Practice and Research December (2003).

Al-Mohizea, I.S. (1986): Microbial quality of camel raw milk in Ryadth markets. Egyptian Journal of Dairy Science, 14 (1): 173-180.

Al-Nakli, H.M. (1984): Inhibition of pathogenic bacteria by camel's milk; relation to whey lysozyme and stage of lactation. Journal of Food Protection, 47 (3): 838-840.

Ayerst, G. (1966): The effects of moisture and temperature on growth and spore germination in some fungi. J. Stored Prod. Res. 5: 669-687.

Bagy, M.K. and Abdel-Hafez, A. (1985): Mycophlora of camel and goat hairs from Al-Arish, Egypt. Mycopathologia 92 (2): 125-128. 
Braun, P.; Buchner, S. and Fehlbaber, K. (2002): Quantitative determination of lipase and their heat stability in food of animal origin. Berl Munch Tiearztl Wochenschr 115 (1-2): 24-29.

Bridge Cooke, W. and Brazis, A.R. (1968): Occurrence of moulds and yeasts in dairy products. Mycopathol. Mycol. Appl. 35: 281-289.

Chu, F.S. (1991): Mycotoxins food contamination, mechanism, carcinogenic potential and presentive measures. Mutate. Res., 259: 291-306.

Conesa, A.; Punt, J.; Luijk, N. and Hondel, C.A. (2001): The secretion pathway in filamentous fungi; a biotechnological view. Fungal Genetics and Biology 33 (3): 155-171.

Cormie, S. (1992): Psychrotrophs and their enzyme residues in cheese milk. A review. Australian J. of Dairy Tech., V. 47.

Desmasures, N.; Bazin, F. and Gueguen, M. (1997): Microbiological composition of raw milk from selected farms in the Camembert region of Normandy. Journal of Applied Microbiology 83, 53-58.

Downey, W.K. (1980): Flavour impairment from pre- and post manufacture lipolysis in milk and dairy products. A review. J. Dairy Res., 47: 237-252.

Dragoni, I. (1979): Contaminazione fungina della uova refrigerate. Arch. Vet. Ital. 30: 129-133.

Ellis, M.B. (1971): Dematiaceous hypomycetes, common wealth. Mycological Institute, Kew, Surrey, UK.

Farah, Z. (1993): Review Article: Composition and characteristics of camel milk. Journal of Dairy Researches 60 (4): 603-636.

Favale, M.S.; Umansky, G.N.; Scarinic, A.E. and Simonetta, A.C. (1994): Incidence of psychrotrophic, proteolytic and lipolytic bacteria in raw milk. Revista Argentina de Lactologia, 6 (10): 25-36. Dairy Science Abstract, Vol. 57, No. 12.

FAO (Food and Agriculture Organization) (1992): Manual of Food Quality Control. 4, Rev. I Microbiological analysis Washington, D.C.

Foster, G.M.; Nelson, F.E.; Speck, M.L.; Doetsch, R.N. and Olson, J.C. (1983): Dairy Microbiology Ridgview Publ. Co., California.

Frisvad, J.C. and Samson, R.A. (1991): Mycotoxins produced by species of Penicillium and Aspergillus occurring in cereals. In Cereal 
Grain: Mycotoxins, Fungi and Quality in Drying and Storage, ed. J. Chelkowski. Amsterdam: Elsevier, pp. 441-476.

Frobish, R.A.; Bradley, B.D.; Wagner, D.D.; Long-Bradley, P.E. and Hairston, H. (1986): Aflatoxin residues in milk of dairy cows after ingestion of naturally contaminated grain. J. Food Prot. 49: 781-785.

Haridy, M.S.A. (1992): Yeast flora of raw milk in El-Minia city, Egypt. Coryptogamie, Mycol. 13 (4): 321-326.

Harrigan, W.F. and McCance, E. (1976): Laboratory Methods in Food and Dairy Microbiology. Academic Press In London Ltd.

Hog, G.S.; Guarro, J.; Gene, J. and Figueras, M.J. (2000): Atlas of clinical fungi $2^{\text {nd }}$ (ed) Centraalbureau voor Schimmelcultures, Utrech. The Netherlands, $1126 \mathrm{pp}$.

Hurley, R.; De Louvois, J. and Mulhall, A. (1987): Yeasts as human and animal pathogens. In: A.H. Rose \& J.S. Harison, The Yeasts. Vol. 1, London, Acad. Press: 207-281.

Jakobsen, M. and Narvhus, J. (1996): Yeasts and their possible beneficial and negative effects on the quality of dairy products. International Dairy Journal, 6: 755-768.

Khedid, K.; Faid, M. and Soulaimani, M. (2003): Microbiological characterization of one humped camel milk in Morocco. Journal of Camel Practice and Research.

Korashy, E. and Hussein, N.A. (2005): Mycobiota associated with cream sold in Assiut Governorate. Assiut Univ. J. of Botany 34 (2): 23-34.

Korashy, E.; Khalil, M. and Gad El-Rab, H. (2006): Major mastitic pathogens in she Camel's milk. 12 ${ }^{\text {th }}$ Cong, 2006 Faculty of Vet., Med. Assiut Univ., Egypt.

Kotula, A.W.; Campano, S.G. and Kinsman, D.M. (1982): Proteolytic and lipolytic activity of Molds isolated from Aged beef. Journal of Food Protection V. 45, No. 3, p. 1242-1244. (November, 1982).

Krishnamachari, K.A.V.R.; Bhat, R.V.; Nagarajan, V. and Tilak, T.B.G. (1975): Investigations into an outbreak of hepatitis in parts of Western India. Indian J. Med. Res. 63: 1036-1048.

Lampert, L.M. (1975): Modern Dairy Products $3^{\text {rd }}$ ed., Chemical Publishing Company, Inc., New York.

Layer, P. and Keller, J. (2003): Lipase supplementation therapy: standards, alternatives and perspectives. Pancreas 26 (1): 1-7. 
Lunn, J.A. (1977): CMI Description of Pathogenic Fungi and Bacteria, Set 53, Nos. 521-530. Kew, Surrey; Commonwealth Mycological Institute.

Mahmoud, Y.H. (1997): Studies on camel's milk. M.V.Sc. (Milk Hygiene), Faculty of Vet. Medicine, Assiut University, Egypt.

Mossel, D.A.A. (1982): Microbiology of Foods $3^{\text {rd }}$ Ed. The University of Utrech., the Netherlands. ISBN.

Moubasher, A.H.; El-Naghy, M.A. and Abdel-Hafez, S.I. (1972): Studies on the fungus flora of three grains in Egypt. Mycopathol. Mycol. Appl. 47: 261-274.

Nasser, Laila A.; El-Shanawy, A.A. and Barakat, A. (1998): Ecological and physiological studies of fungi associated with camel hair. $8^{\text {th }}$ Congress Fac. Vol. Med. Assiut University, Egypt, pp. 243-254.

Ottogalli, G. and Galli, A. (1972): Surface microflora of teleggio cheese. Scienza Tecnica Lattiero Casearia, 23 (6): 396. (Dairy Sci. Abst.).

Paterson, R.R.M. and Bridg, P.D. (1994): Biochemical techniques for filamentous fungi. Int. Mycol. Instit. CAB. International Survey, p. 21, UK.

Raper, K.B. and Fennell, D.I. (1965): The genus Aspergillus. Williams and Kilkins, Baltimore, USA.

Richard, J.L.; Peden, W.M. and Williams, P.P. (1994): Gliotoxin inhibits transformation and its cytotoxic to turkey peripheral blood lymphocytes. Mycopathologia 126: 109-114.

Roae, M.B.; Gupta, R.C. and Dastur, N.W. (1970): Camel's milk and milk products. Indian Journal of Dairy Science 23: 71-78.

Robinson, R.K. (1990): Dairy Microbiology. $2^{\text {nd }}$ Ed. Chapman and Hall, London, New York, pp. 324-390.

Sabry, Y.M. (2001): Thermoduric Psychrotrophic Bacteria in Milk and some Dairy products. M.V.Sc. (Milk Hygiene) Faculty of Veterinary Medicine, Assiut University, Egypt.

Saxena, R.; Sheoran, A.; Giri, B. and Davidson, W. (2003): Purification strategies for microbial lipases. Journal of Microbiology 52 (1): $1-12$.

Spillmann, H. and Ceiges, O. (1983): Identification von Hefen und Schimmepifzen and Bombierten Joghurt-Packungen. Milchwissenschaft 38: 129-132. 
Stelma, G.N. Jr. (1989): Aeromonas hydrophib. IN: M.P. Doyle (ed.) Food borne Bacterial Pathogens. Marcel Dekker, Inc., New York, 1-15.

Stoloff, L. (1976): Occurrence of mycotoxins in foods and feeds. In J.V. Rodricks (Ed), Mycotoxins and other fungal related food problems. Advances in Chemistry Series 140, American Chemical Society Washington, D.C. 23-50.

Terao, K.; Ito, E.; Kawai, K.; Nozawa, K. and Udagawa, S. (1990): Experimental acute poisoning in mice induced by emestrin, a new mycotoxin isolated from Emericella species. Mycopathologia 112: 71-79.

Teshager, S. and Bayleyen, M. (2001): Bacteriological quality of raw milk of camel (Camelus dromadarius) in Alar region (Ethiopia). Journal of Camel Practice and Research, 8: 51-54.

Ullman, V. and Blasins, G. (1974): A simple medium for detection of different lipolytic activity of microorganisms. Zentrabl. Bakteriol. Hyg. II Abt, A., 229: 264.

Wyllie, T.D. and Morehouse, L.G. (1977): Mycotoxic fungi, mycotoxins, mycotoxicosis. An encyclopedic hand book volume. 1. Marcel Dekker, Inc. New York and Basel.

Yagil, R. (1982): Camels and camel milk. Rome: Food and Agriculture Organization (FAO) Animal Production and Health Paper No. 26, pp. 14-19.

Zagorski, O.; Maman, A.; Yaffe, A.; Meisles, A.; Van Creveld, C. and Yagil, R. (1998): Insulin in milk-a comparative study. International Journal of Animal Science, 13: 241-244. 